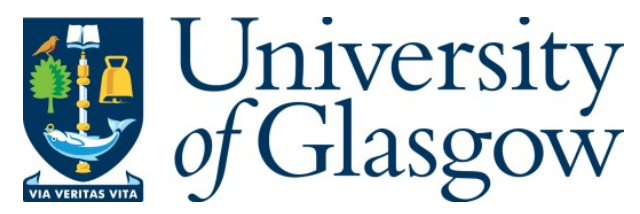

Maitra, S. and Maitra, S. (2019) Skill formation and precarious labor: the historical role of the industrial training institutes in India 1950-2018. In: Jammulamadaka, N.

P. (ed.) Workers and Margins: Grasping Erasures and Opportunities. Palgrave Macmillan: Singapore, pp. 21-43. ISBN 9789811378751

(doi:10.1007/978-981-13-7876-8_2)

There may be differences between this version and the published version. You are advised to consult the publisher's version if you wish to cite from it.

http://eprints.gla.ac.uk/171294/

Deposited on: 12 October 2018

Enlighten - Research publications by members of the University of Glasgow http://eprints.gla.ac.uk 


\title{
Skill Formation and Precarious Labour: The Historical Role of the Industrial Training Institutes in India 1950-2018
}

\author{
Saikat Maitra, Assistant Professor, Indian Institute of Management - Calcutta
}

\author{
Srabani Maitra, Lecturer, School of Education, University of Glasgow
}

\section{Introduction}

Persistent skill gap has always been a concern with policymakers and corporations in India as India endeavours to 'develop workers who are flexible, adaptable, and adept in behavioural, interpersonal and inter-functional skills' suitable for the new economy (especially the service sector) (Maitra \& Maitra 2015, p. 318; Majumdar 2016; Mehrotra 2012). As various reports indicate, youth un/underemployment continues to be a critical issue in India coupled with a rise in informal and vulnerable occupations in both manufacturing and the service sectors that undermines the prospects of reducing working poverty (ILO 2018; Mitra \& Verick 2013). ILO (2018) data shows that out of the 1.4 billion people estimated to be in vulnerable employment globally this year, 394 million or more than a quarter will be in India alone. Skill training and education are considered important means to address such issues of vulnerability and working poverty.

According to the recent Human Development Report (2016) by UNDP, average human development has improved globally; yet marginalized sections continue to suffer basic forms of deprivation. Unemployment and deepening socio-economic inequalities are two of the most fundamental forms of such deprivation (Jahan 2016). Learning and training are considered efficacious strategies for addressing and mitigating the problems of inequality as underscored by many policymakers and academics. Accordingly, in the last few years several policy documents have recurrently emphasised the need for the workers to continue to learn and get trained in cognitive as well as interpersonal skills to remain competitive in the global labour market.

This chapter seeks to understand the history of industrial development in India through the state-led institutional arrangement for skill-training. As a late industrializing state, institutionalized skill training for the creation of a stable and disciplined work force in India was seen as critically important to transform the rural agricultural economy of the country into a modern industrialized state. As part of the second Five Year Plan (1956-1961) that outlined the major governmental policy on industrial development in India, skill-training was seen as critical to transform the vast rural agricultural workforce into a modern and disciplined labour-force with technological proficiency. Employment generation and the need for a stable work force in the emerging industrial landscape of India made skill-training a vital policy imperative of the post-colonial Indian state. Even in the contemporary period, the emphasis on the industrial manufacturing jobs through the 'Make in India' program is seen as a cornerstone of developing industrialization in the present context. 
Industrial training establishments are considered crucial institutions for providing skill training at the entry and intermediate levels and assumed to facilitate successful employment and careers to young trainees. The role played by the state in the establishment of institutions for skill-training such as the ITIs were seen as a crucial function of the state in reproducing labour (through its education and training) in order to provide employment, attract private capital investments and facilitate the creation of a modern work-force. Yet, relatively little historical work exists in Indian labour studies that specifically explore skill training as a crucial and significant aspect of the larger narrative of industrial development in India. The focus of this chapter on the state-led ITIs is especially important, as the ITIs have continued to remain as the main training institutes for youth populations seeking to enter the industrial sector for most of the post-colonial period in India.

However, as we demonstrate in this chapter, by examining the role of ITI in skill training and its interaction with employment, the scope for labour market integration of young ITI graduates are quite slim. Lack of effectively coordinated skill training coupled with mismatch in employability skills and uneven and concentrated industrial growth are creating a pool of atypical, non-standard, cheap workers having part-time employment and more home-working, casual and contract jobs.

\section{Skill Training Policy in India: Some recent initiatives}

As Nayana Tara and Sanath Kumar (2016) point out, the magnitude of skilling India is huge given that 12.8 million annually enter the labour market for the first time, 72.88 million are employed in the organised sector while 387.34 million work in the unorganised sector. Furthermore, a growing population also poses barriers to effective skill training. In addition, 298.25 million of existing farm and nonfarm sector workforce will need to be skilled, reskilled and upskilled (Government of India 2015). Therefore, various initiatives have been undertaken by the government of India to mainstream skill training, especially for the economically marginalised youth.

Towards addressing this problem, 'Coordinated Action on Skill Development' was proposed by the Planning Commission and approved by the Cabinet in 2008, for achieving the 11th Plan objective of inclusive growth and development by creating a pool of skilled workforce that would meet the employment requirement across various sectors of the national economy (Planning Commission 2008). It is estimated that building on this policy of 'Co-ordinated Action on Skills Development', as of 2012 the Government of India has facilitated the setting up of more than 9000 industrial training institutes, 3500 polytechnics, in addition to the 8000 engineering/other degree institutions, to provide training at different levels of skilli.

This initiative was complemented by the adoption of the National Skills Development Policy in early 2009. India has also partnered with international agencies such as International Labour Organisation (ILO) and Organisation for Economic Co-operation and Development (OECD) in addressing skill training issues and to develop skill training 
strategies for improved productivity, employment growth and development. In 2010 and 2011, OECD under its 'Skills and Employment Strategies in Southeast Asia Initiative' (ESSSA) held two meetings in Tokyo and Shanghai to discuss how to integrate skill development strategies in Asian countries. India, was among the 15 Asian countries that participated in the meetings to discuss how to build a system for skill training and align the links between training and industry needsii.

Recently in 2015, the commitment to skill development was renewed through the establishment of the Ministry of Skill Development and Entrepreneurship (MSDE). In 2015 the Skill India mission was also launched with a target of training over 400 million people by 2022 iii. Skill India mission was envisaged as a demand driven, skill training initiative, in particular, targetting skilling of young people who lack formal certification, such as the weaker and disadvantaged sections of the society (Government of India, 2015). It is being promoted with the tagline, "Kaushal Bharat, Kushal Bharat" (skilling Indians will result in a happy and prosperous nation), this . In addition, it has been planned to assess and certify 10 lakh youth for the skills that they already possess through an initiative known as 'Recognition of Prior Learning' (RPL)iv.

In the context of this policy emphasis on skilling, Industrial Training Institutes (ITIs) and the Industrial Training Centres (ITCs) have emerged as significant constituents of the current skill ecosystem in India, and they play a key role in providing formal skill training to young people, especially from the marginalised sections. ITCs are institutions funded and managed by private organizations such as NGOs. State-funded ITIs started operating in the 1950s to primarily train young school leavers. As of 2018, there are a total of 11,964 (state funded 2284 and privately owned 9680) ITIs across the country. Training is imparted in 126 trades (73 in engineering, 48 in non- engineering and 5 exclusively for visually impaired) of duration 1-2 years ${ }^{v}$. The supply-driven training curriculum is standardised and designed by the National Council for Vocational Training (NCVT) and implemented at each ITI under the supervision of the State Council for Vocational Training (SCVT). Usually, 70\% of the training is practice oriented while the rest is theory based, although much of the practical training is imparted within the ITIs. There is 30\% reservation for women within ITIs although women's enrolment is still low because of various socio-cultural norms and responsibilities (Mehrotra \& Mehrotra, 2018). Successful trainees are awarded a National Trade Certificate, nationally \& internationally recognized under the aegis of National Council for Vocational Training (NCVT) ${ }^{\mathrm{vi}}$. As one of the major training institutes, ITIs have a high impact on the formal vocational education in India (Pilz 2016). ITIs are considered crucial institutions for providing skill training at the intermediate levels and assumed to facilitate smooth pathways to employment and successful careers in manufacturing, construction and the service sector to young trainees.

Thus, in the following sections, through a combination of conceptual insights drawn from Indian labour historiography and ethnographic participant research we explore the historical and ideological contestations over the meaning, nature and scope of industrial skill training in state-sponsored industrial Training Institutes (ITIs) in their attempts to create a disciplined, committed, yet cheap labour force in India. 


\section{Selection of Research Methods and Field-Sites}

This paper draws on conceptual insights from Indian labour history to address the question of historical and ideological shifts in the structure and pedagogic principles of the ITIs. In addition to the theoretical inputs from labour history, ethnographic fieldwork was conducted in a state run Industrial Training institute in Kolkata in the Indian state of West Bengal. The choice of this regional ITI has been motivated by contrasting and uneven histories of regional industrial growth in Eastern India and especially in West Bengal.

Eastern India, and especially the state of West Bengal, during both the colonial and early post-colonial period in India has witnessed relatively significant concentrations of industrial growth in sectors such as jute manufacturing, heavy engineering, iron and steel manufacturing and chemical industries. This industrial growth was achieved through both public and private capital investments in West Bengal, which made the state one of the most advanced industrialized regions in India till the 1980s. However, increasingly hostile capital-labour relations in the region along with mass-scale industrial capital flight led to a massive de-industrialization of West Bengal from the 1990s. Through ethnographic interviews and compilation of life histories of present and former students of the ITI in Kolkata, this paper explores how the ITI trained workers in the region understand the relevance of their skill training under contemporary regimes of de-industrialization.

Semi-structured interviews were conducted with ten current students of the ITI. The interviews focused on the aspirations, hopes and fears of the students about their job prospects and future social mobility based on their ITI training. Interviewees were identified through snow ball sampling. More structured interviews with pre-circulated questionnaires were conducted with five faculty members in the ITI selected for the study to explore how faculty members perceived the current institutional and course structures as relevant for skill-training and employability of students. Finally, keyinformant interviews were conducted on the continuing relevance and importance of the ITIs with five members of the Directorate of Vocational Education and Training, which supervises all the ITIs in India.

Focus Group discussions were also conducted with ten alumni from the ITI selected for the study. The discussions focused on how relevant the skill training has been as imparted by the ITIs for securing employment, the possibilities for career advancement through industrial training and the difficulties in labour integration faced by the former students of these institutions. The participants for the focus groups were arranged through snow-ball sampling methods and through referrals by the current ITI faculties.

Member Checks: Further to the usual triangulation, member checks were assured in the final phase of the research with long discussions and informal presentations on the research findings before students and faculties. The member check presentations assured the authenticity, veracity and validity of the preliminary research findings and elicited additional insights. 


\section{Historical Over-view of industrial Skill Training in India}

The period from 1950 - 1970

The paradigm of planned economic development with a distinctly socialist tendency adopted by the Nehruvian Indian state after independence in 1947, assimilated industrialization as the primary growth sector from its second Five Year Plan extending from 1956- 1961 (Parry 1999; Roy 2007). The Second Five Year Plan not only envisioned rapid industrialization of the country in heavy manufacturing sectors (such as iron and steel) through large-scale and intensive capital investments by the state in the form of setting up state owned enterprises, but it also took up the responsibility of training and skilling the work-force to meet the high-technology production scenarios of both state and private industrial enterprises (Kohli 2006, 2012). Such training responsibilities had both an utilitarian and ideological function whereby the state's function in labour reproduction (at the level of educating and training workers) were aimed to: 1 . fill in the demand for a large, skilled work-force in the resurgent industrial scene in India in the 1950s; 2 . to push for a nationalist and socialist agenda for development that emphasized the transformation of youth populations into a disciplined, modern and responsible work-force through skill training and employment generating education. In keeping with the Second Five Year Plan stress on industrialization, foreign collaborations and skill transfers for training workers were initiated for example with help from the Ford foundation in the 1950s.

It was this emphasis on training by the Indian state that led to the establishment of the first Industrial Training Institute (ITI) in the early 1950s along with the establishment of the state appointed National Council of Vocational Training for overseeing the curricular content and institutional quality of the various regional ITIs. Moreover, the ITIs were themselves part of a broader tripartite division of technological education and training emerging in the 1950s in India. Thus, the Indian Institute of Technologies (IITs starting in 1951) and other degree granting regional engineering colleges formed the top tier of technological education; the polytechnical institutions granting diplomas formed the middle layer; and the ITIs occupied the lowermost ranks of this division. The ITIs from their very inception were conceptualized as pedagogic sites by the Indian state for transforming primarily underclass youth populations, after secondary education, into a technologically trained, stable, disciplined and employable industrial work-force (Agrawal 2012). These institutions during the period of large-scale state led industrialization in India were measures for poverty alleviation and employability of youth populations by integrating them into the emerging national industrial landscape (Gasskov et al. 2003; Goel 2011; Parmar et al. 2015; Sen 1989).

From the later half of the 1950s up to the 1960s a relatively large percentage of such ITI trained youth workers did manage to find reasonably privileged employment contracts in the emerging steel mill towns of the nationalized enterprises located at various parts of India such as Bhilai, Durgapur, Rourkella, Bokaro or the large hydroelectric power projects in the Damodar Valley or the Hirakud region. Such workers, recognized as highly skilled labour, had high wage rates, guaranteed employment contracts, housing 
and medical benefits along with facilities for their family dependents. In Jonathan Parry's ethnography of such workers in state-owned enterprises such as in the nationalized steel town of Bhilai in central India, these workers constituted the 'aristocracy of labour' enjoying a high wage rate and multiple social benefits (Parry 1999).

By the 1970s, however, this picture of skilled workers institutionally trained in the ITIs and being absorbed as a stable workforce in public and elite private enterprises gets substantially altered. As Parry and other researchers of industrialization of India have suggested, increasingly larger sections of the work-force in both nationalized enterprises as well as private corporate ones were recruited as casual workers with considerably less wages and benefits and were routinely demarcated as 'unskilled' or 'apprentice-trainees', even while performing the same job complexities and holding similar credentials as the permanent labour-force (Parry 1999; Parry \& Strümpell 2008). With investments by the Indian state in public sector undertakings drying up along with rationalization of the work processes in these companies, increasingly larger percentages of jobs were being performed by casual, 'unskilled' workers who could be paid substantially less than the 'labour aristocracy' fortunate enough to have permanent positions. As the developmentalist agenda of the Indian state in promoting industrialization and employment growth through direct capital investments were faltering, casualization of the work-force was also becoming a general trend in the Indian industrial sector (Parry 1999). In Mark Holmström's description of the Indian working class as a 'mountain' with deeply hierarchical structure with several intermediary 'classes of labour' the labour aristocracy sits right at the summit while the casual 'unskilled' or 'semi-skilled' work-force with similar credentials but no permanent job contracts would come way below the slope (1984). Moreover, members of underprivileged social groups such as Dalits, Adivasis and women workers increasingly came to form the casual labour force further compounding their economic and social marginalization as workers in many of the large nationalized and elite private enterprises (Sanchez 2016).

\section{The Period from 1980s to the Present}

While the liberalization of the Indian economy did not happen till 1991, the Indian state from the 1980 onwards were already shifting considerably from its socialist commitments to planned, state-led industrial development and employment generation towards what Atul Kohli has described as a 'pro-business' state that emphasized the role of private capital in the industrial sector (2006). Central to this policy shift was not only the continuing curtailment of public sector investments in the industrial sectors, but also policy regulations such as tax-incentives for private capital to invest (Kohli 2006). This 'pro-business' stance of the Indian state subsequently embraced a more free-market oriented approach to industrialization with the opening up of the Indian economy in 1991. This did not mean that the diminishing of the interventionist role of the state: rather it signified a qualitative change in the nature of intervention where the 
Indian state was assuming the role of a facilitator for private capitalist investments (Levien 2012). This role of the facilitator would for instance entail the state to provide cheap land often for building up Special Economic Zones, industrial parks or Industrial corridors for private industrial development (Levien 2012, 2013a). The newly emerging spatial formations for industrial manufacturing such as the Special Economic Zones or Industrial Corridors meant that there was a progressive shift of industries from large urban centers such as Mumbai, Ahmedabad, Kanpur or Kolkata that were traditionally the bastions of industrialization. This has not only led to a gradual de-industrialization of Indian cities but also a progressive 'invisibilization' of industrial production which are often tucked away in highly regulated spaces such as Special Economic Zones.

Such deindustrialisation had direct effect on the trainees in ITIs who increasingly found it difficult to get jobs related to their training (Kumar, 2016). The issue was further compounded by the negative image and low esteem for ITIs among the employers who started regarding the trainees as lacking in both employable or commercial skills (Kumar, 2016). As Mehrotra and Mehrotra (2018) point out, there are three kinds of skills important for the labour market, 'cognitive skills (reading, writing, numeracy); employability skills (team work, computing skills, communication); and vocational skills (trade or occupation related) (p.15). ITIs are increasingly being critiqued for not inculcating employable skills among its students (Kumar, 2016; Mehrotra \& Mehrotra, 2018). As well, curricula of much of what is taught in ITIs are not too well aligned with the industry needs and continue to be conventional and inflexible (Kumar 2016). Lack of employable skills is an acute issue in the context of the fact that by 2022, 109.73 million workers would be required to fill in skill based employment in around 24 sectors across manufacturing and service industry (Mehrotra \&Mehrotra 2018). Since the focus in many of these sectors are on employable skills, ITIs should be prepared to well train the workers for the emerging possibilities.

Additionally, there are no opportunities for upskilling, retraining and/or lifelong learning of the workers with the ITIs. Workers are hardly made aware of their labour rights within the workplace and expected to upgrade their skills on their own either to remain employed or to move between different forms and sectors of work (Mehrotra \& Mehrotra 2018). Most often, a vast majority of the 'skilled' labour-force from ITIs has to work under conditions of extreme precariousness as casualized work-force with wage levels equating that of 'unskilled' workers and scarce employment benefits. The emphasis on incorporating of 'soft-skill' and etiquette training by the ITIs, ostensibly to increase the employability of workers, is in many ways to incorporate qualities of docility, passivity and self-reliance in workers to survive the decreasing employment guarantees under free-market conditions of industrial labour (Maitra \& Maitra 2015).

\section{A New Industrial Precariat?}

In this section, we ethnographically focus on the coping strategies adopted by contemporary students in an ITI located in southern Kolkata for accessing industrial sector employment in the context of large-scale de-industrialization in West Bengal. West Bengal is a key state for human resource development - being the fourth most 
populous and second most densely populated state of India. Availability of working age population measured from the 15-59 age group population, is estimated to grow from 604 lakhs in 2012 to 665 lakhs by 2022. Availability of a large pool of human resource in the state, makes West Bengal a possible source of manpower for outside of the state, as well (NSDC 2012-2017). There are currently 52 government ITIs in West Bengal, 71 government ITIs running under PPP model while another 30 ITIs are soon to be operational (West Bengal 2017). Government of West Bengal intends to operate ITIs through Industry Association and is planning to train around 5,00,000 trainees under Utkarsh Bangla, a flagship initiative of the state launched in 2016. The West Bengal government launched this initiative for placement linked short-term skill trainings across the State of West Bengal (West Bengal 2017).

The ethnographic interviews, focus group interactions and life histories of students, as well as recent alumni, conducted as part of this study suggests that inter-state migration is the key strategy for labour market integration in the industrial sector for most of the ITI graduates. Migration can be both to northern and western Indian states such as Gujarat, Maharashtra, Haryana and Rajasthan as well as southern states such as Andhra Pradesh and Karnataka. The developed industrial landscapes of these states provide the main incentives for migration. However, for most students from the ITI, the experience of migration is often intermittent and episodic as well as uncertain. In the context where the ITI does not have any developed institutional processes for campus recruitments, students are essentially expected to search for and secure their employment through their own initiatives upon graduation.

Information is vital as to which potential companies or organizations are offering jobs for which particular skill sets. Typically such information is gleaned through various networks such as students unions, faculty members, former students visiting the ITI as well as relatives and friends. Of these networks, usually former students who are currently employed in industrial sector jobs are the most reliable sources of information as they are not only able to provide information as to where to apply for jobs but also to help with the application process like preparing a suitable bio-data. The senior students are also able to groom present students for the interviews, especially where such interviews can be potentially difficult for young ITI graduates with no prior job experience. Furthermore, once a candidate or a group of candidates from the ITI are able to secure jobs in the same corporation or in the same locality, the former students are expected to help in the initial period of settling in a new location by finding cheap accommodation. Reminiscent of labour migration patterns discussed by Jan Breman in other contexts, such as for seasonal agricultural workers, the migration of workers trained in the ITI thus typically takes place along established routes and to specific destinations where there are some forms of established networks of support in place (1999). This network ensures that the young graduates, often with very limited economic resources and usually traveling by themselves for the first time, are able to find accommodation as well as other resources such as food on credit till the time they get their first salaries. 
The importance of this network in labour migrations amongst ITI workers is for instance borne out in the case of Sunandan, an ITI graduate who specialized in machine tool operations. As advised by his elder cousin who had also studied in the same ITI, Sunandan had, from the very beginning of his enrolment in 2012, taken an active interest in the student union activities. While student politics did not really interest him at all, he was diligent in cultivating relationships with the senior students as well as past alumni that union members were in touch with. His efforts at cultivating a good social network paid off when he was able to find a job in a stainless-steel utensil manufacturing unit located in an industrial park near Jaipur in Rajasthan, right after his graduation in 2014. However, the sheer joy of finding employment right after the completion of his studies was short-lived. For the entire stretch of almost a year and half that he worked in the factory, Sunandan could only afford to live in a small cramped room that he shared with five other workers. Sunandan like most of the other workers in the corporation had to agree to rent a room referred to by local Rajasthani supervisors even though the rent was prohibitively high, as the industrial park was located a long distance off from the main city of Jaipur with no public transport or a large choice of places to rent. While the rented building was close to the factory, yet the living condition was terrible where in summer the room became like a furnace. "All I remember from my time in Rajasthan was the heat and the lack of sleep" is how he described his time working in the factory.

While the living condition was deplorable, where he could have enough space to put his sleeping mattress on the floor only when some of his co-workers went for their shifts, the actual working conditions were even worse. According to Sunandan even the most basic safety provisions were often missing and the new workers were constantly exposed to potential accidents while shaping or polishing the stainless steel utensils. The situation was further compounded by the constant harassment of the floor managers to speed up the work. Often new workers like Sunandan would be too scared to even take a bathroom break as this might immediately result in verbal abuse, monetary penalties and even the threat of physical violence. As Sunandan quickly discovered, the harassment was particularly severe for the large contingent of migrant workers like him from eastern India - from states like West Bengal, Assam and Odisha. While the company seemed to favor these migrant workers for their docile acceptance of the working conditions nonetheless such workers also were the most disposable and maltreated in the everyday workings of the factory. On the other hand almost all the floor level managers and supervisors were men from Rajasthan who constantly complained about how lazy the migrant workers were and invariably assigned them the most hazardous and exhausting jobs. No matter how much Sunandan and some of the other migrant workers laboured, they seemed to be always lagging behind the schedule or their work was found to be imperfect. 
In the initial months, he had really tried to put in as much attention and effort as he could so as to make sure that his work was up to the standard demanded by the supervisors. However, despite all his efforts almost everyday the volume of complaints kept increasing. The constant complaints about the efficiency and quality of work was not just limited to him but was also in the case of most of the new migrant workers in the organization that Sunandan interacted with. While for a long time he regarded these complaints as reflecting his own inability and lack of proficiency, some of his coworkers explained that there was a different reason for such persistent complaints. While initially Sunandan was hired on probation for a period of six months earning substantially less than the regular salary, he was supposed to receive full payment and benefits, like paid leave, after the six month probationary period, provided his work was satisfactory. Yet, the regular list of complaints meant that he was not only losing part of his salary through fines, but also his contract was terminated just before the completion of the six month period of service.

Without any employment in Rajasthan, he was compelled to return to Kolkata where he tried desperately but unsuccessfully to find another manufacturing job. His previous job experience was in fact a big hindrance as the final termination letter from the company was explicit in its condemnation of his performance. However, after a few weeks the previous company offered to re-hire him but on condition that he would be again put on a six-month probation. Without any other immediate prospects for employment, Sunandan decided to accept the offer. In this second tenure with the company, the same cycle of harassment, complaints, depleted salary and the eventual lay-off was again repeated. Moreover, this time the supervisors even told him that he should accept this particular form of contractual work punctuated by periods of lay-off as the company would never actually give him the full contract. The periodic lay-off also meant that the company could afford to hire skilled workers like Sunandan only when the actual market demand was high and not have to pay salaries when the demand flagged off. He also agreed to share a percentage of his salary with his immediate supervisors every month so that the fines related to his performance would be less frequent, even though the supervisors would continue to register a certain number of complaints about his performance every week.

This cycle of complaints and probation meant that the experience of migration was also episodic where he would have to return to Kolkata after his periods of probation to be re-absorbed after a short period. After his third term of probationary labour, Sunandan decided to not continue with the job in Rajasthan as his health was very badly affected by the stress related to this precarious job. Presently employed as a security guard, Sunandan continues to search for industrial jobs in or around Kolkata but not with any success so far. Along with Sunandan, several of the other ITI alumni interviewed for this project recounted similar experiences related to industrial sector jobs currently securing an initial job was not extremely challenging once they were amenable to migrate. However, the employment conditions of these jobs typically meant 
intermittent periods of precarious, contingent labour contracts with low salaries and almost no benefits. Typically, the periods of employment would be furthermore interspersed with periods of unemployment, which could stretch from a few weeks to a few months depending upon market demand necessitating the corporation requiring a large skilled labour force, which would mostly be filled up with migrant workers from the ITIs located in eastern India, and especially from West Bengal with relatively better ITIs imparting better skill training.

The paucity of industrial jobs in West Bengal usually made such students, moreover, willing to accept the episodic and exploitative forms of migrant employment without taking recourse to any legal or political measures. In the context of large scale flight of industrial capital from eastern India and the concentration of the manufacturing sectors employment in spaces such as industrial parks, industrial corridors or Special Economic Zones where labour laws are likely to be less enforced, migrant workers like Sunandan are especially susceptible to exploitative forms of labour control regimes as brought out through their experiences of precarious labour migrations (Cross 2014; Levien 2013b; Levien 2015). Lacking both language skills and extensive social networks in their places of work post-migration, they find that they have very little political, economic, legal or social leverage with which to put forward any demands for equitable employment conditions. They mostly remain an alien group of migrant workers who are often deeply resented by the local populations for taking over the limited employment opportunities. This condition of resentment towards migrant workers is not only extremely favorable for the corporate industrial organizations in exploiting a steady source of cheap but accredited and skilled labour force, but also help to block any potential solidarity between migrant and non-migrant workers on the shop-floor.

Political mobilization by migrant workers to demand better working conditions is thus obfuscated in a situation where they are typically isolated and alienated from the larger body of ethnically indigenous co-workers. In fact in many cases, low-level supervisors and managers carefully foment the ethnic split between migrant and local workers by assigning the most hazardous jobs to the former groups as a strategy to control any broad-based labour solidarity. Given the large volume of available skilled workers from ITIs in states such as West Bengal, most companies are interested in retaining the same migrant worker at the lowest possible wage levels and then replacing the worker with a new one as soon as there might be legal obligations to increase the wage. While a core group of work processes in relatively low technology companies (like the one Sunandan worked in) would be performed by local or migrant workers with long term and secured employment contracts, most of the peripheral work would be performed by a disposable group of migrant workers who require very little commitment in terms of inhouse training. 
While migration provides one of the key strategies for finding employment in the industrial sector despite the associated problems, the other strategy favored by ITI students is to use the institute accreditation to explore job opportunities in the emerging retail and service industries in Kolkata. Such jobs typically do not actually utilize any of the skill sets related to the manufacturing sector typically taught by the ITI, and the students by accepting such jobs usually forfeit their chances of being absorbed in the industrial sector eventually. However, the advantage of accepting jobs in the services or retail industries is that they can continue to stay in Kolkata and explore various options for employment including appearing for various examinations for securing government jobs. Nikhil, who trained as a refrigerator mechanic, suggested that his present work as a barista in a café chain gives him the opportunity to regularly appear for government service related examinations. Moreover, he likes to often take extra shifts and save as much of the money as possible so that he can eventually enroll in one of the tuition programs preparing students for government employment examinations. In the event where his family would not be able to afford tuition fees necessary for such tuition, his best option lies in saving enough money to take a break from his current work for a few months to prepare intensively for the examinations.

With a relatively large number of entry-level jobs available in the services industries in Kolkata presently, Nikhil does not see any problems in getting his job back in the café if he is not successful with the government job examinations. Completing his final year in carpentry, Suresh informed us that he has already contacted several friends who might refer him for a retail job in a large shopping mall in Kolkata. While such a job would not require any of the skills he is currently learning at the ITI, yet the advantage of being a student is that he will get a post-secondary government accreditation at a relatively young age with almost no expense. Unlike Nikhil, Suresh would eventually like to open his own small carpentry workshop either by himself or in collaboration with some of his colleagues in the ITI. He aspires to work in the retail industry for a period of five years to save some working capital in order to start his own workshop. Both Nikhil and Suresh see their tenure at the ITI not in terms of preparing them for an eventual professional career on the basis of skill-training but a temporary arrangement, a form of productive 'time-pass' which might lead to other productive forms of employment or small time entrepreneurship (Jeffrey 2010).

The option of migrating in search of employment in the industrial sector are rejected by both of them as ultimately getting entrapped in a vicious cycle of low-end and physically exhausting jobs from which there is hardly any possibilities for upward mobility. The ITI accreditation is for students like Nikhil and Suresh desirable only because of the low financial commitments required by their families in contrast to enroling in a regular degree college, which also may not guarantee any better prospects for jobs. As pointed by Sujit who completed his ITI training in 2015, most of his colleagues at his entry-level job in a courier company have been to degree colleges and despite the longer years of studying have fared not so much better than him in the job market. However, Sujit also 
pointed out the possible pitfalls of working in the low-end services industries like his present courier delivery job. Usually the low salary compounded by the flexible hours of such jobs leaves very little time or money to plan for the future. In a focus group interview, Sujit dismissed the aspirations of Nikhil and Suresh as frankly impractical because unless the families are economically well-off, low-end services or retail jobs does not typically allow entry-level workers to save enough money to open a work-shop or allow the luxury of not working for months at a time.

Moreover, once a worker has been without a job for sometime, he usually finds it very difficult to find any employment with so many young men and women, often with college degrees, who are desperate to get a job in the retail and services industries in Kolkata. Referring to his friend Ajay he suggested how after graduating from the ITI in 2014 , he had taken a job in an online food delivery platform so as to save enough money to afford tuition classes for government employment examinations. Yet, after four years Ajay has still not managed to save any money to either enroll in tuition classes or to take a long break from his employment in order to prepare for the examinations. For Sujit, working in retail or service industries in Kolkata is also about getting entrapped in repeated cycles of precarious, low-end jobs like for migrant industrial workers from his institute, with no possibilities of any meaningful social mobility. While the ITI education for Sujit, did provide him with a low-cost government education at a comparatively young age, the lack of meaningful employment opportunities in Kolkata or West Bengal constantly exposes the ITI students to various forms of exploitative job relations.

Sujit's perceptions about the career prospects and employment opportunities of present ITI students seem to be borne out by most of the students we interviewed where most of the jobs - either as migrant workers in industrial settings or in the service industries of Kolkata - are inevitably precarious and with little chances for career development and meaningful social mobility. Drawing on the British sociologist Guy Standing's work, we can suggest that most of the young ITI graduates are becoming part of an emerging 'precariat' with relatively high levels of educational attainments and skill-training but nevertheless caught up in increasingly vicious cycles of precarious and contingent employment relations (2014). ITI education in the context of uneven development of industrial capital in contemporary India seems to be creating a large pool of skilled and flexible labour force whose ability to demand labour rights and productive employment relations are increasingly diminishing. This is especially the case in contexts such as Kolkata/West Bengal with an industrial labour market not able to absorb most of the students trained in the ITIs in the state.

\section{Conclusion}

The discourse of skill and worker 
This chapter began with the intent to understand the history of industrial development in India through the state-led institutional arrangement for skill-training. As a late industrializing state, institutionalized skill training was a policy imperative. Our analysis and insights from ethnographic observations, enable us to draw the following conclusions.

As scholars such as Srirupa Roy have argued, the Second Five Year Plan was a policy document by the Indian state not only to boost industrialization and modernization of the economy through state led investments in sectors such as hydroelectric dams and the setting up of heavy Steel Mills by the state, it also envisioned a new Indian workersubject who was free from pre-modern irrationalities and inculcated a scientific mind (2007). Industrial training and technological education were seen as critical to developing the scientific bent of mind of the Indian population as a whole and of workers in the industrial sector more specifically. Skill training was seen as fundamental for emancipating Indian industrial workers from their supposedly deeprooted attachment to the rural, agricultural economy - a systemic process of social engineering for transforming the rural, peasant character of industrial workers into a disciplined and committed urban proletariat (Morris 1965). This proletariat could then be employed and integrated seamlessly into the upcoming and modernized state-owned steel mills and company towns of Bhilai, Rourkella, Durgapur and so on.

What is important to note from the preceding discussions is how skill training and not de-skilling of workers has been a central feature of India's post-colonial industrial development. For example, in Harry Braverman's well-known critique of the trends towards 'monopoly capitalism' under industrialization in the twentieth century, workers have become progressively de-skilled as a result of the specific forms of management control over work processes (1974). For Braverman, the early twentieth century emergence of Taylorist principles of scientific management breaking down all production processes into a set of smaller, simpler, routinized and measurable tasks had meant that most industrial work processes could be performed by a cheap, replaceable and de-skilled work-force (1974).

In contradistinction to Harry Braverman's argument we see that in late-industrializing contexts like in post-colonial India, work-place rationalization and modernization of industry necessarily devolved around the institutional arrangements for creating a technologically proficient and skilled labour-force and not de-skilling of the labour-force (Crisp 1983, Parry 1999). For instance, Jonathan Parry uses the notion of 'labour aristocracy' to suggest how a relatively small and elite section of the Indian industrial work-force, who are mostly employed as permanent workers in state-owned public enterprises or formalized sections of the private corporate sector, have garnered relatively high wage and employment privileges by virtue of their recognition as a skilled work-force (Engels 1993; Hobsbawm 1968; Parry 1999). Moreover, such privileged access to the status of skilled workers has been traditionally and fiercely guarded by Trade Union organizations as well as state legislatures and corporate capitalist strategies for employing a vast majority of workers as casual, lowly-paid and 'unskilled' labour-force (Sanchez 2012). 
Increasingly, capital flight and fear of such flight and the consequent deindustrialization of former regional industrial hubs like in West Bengal have been used as a powerful tool by both the Indian state and corporate industrial capital to control and manage the industrial labour force. Both the Indian state and regional provincial governments, eager to attract both multinational and national industrial capital are promoting the ITIs today as a source of cheap, docile and passive labour for both the industrial as well as post-industrial private capital. Thus ideologically, the function of the ITIs under India's economic re-structuring programs from the 1980s and especially the 1990s have significantly shifted from the reproduction of labour for state-led industrial growth and employment generation to attracting private corporate capital investments.

The privatization of public education in India, has further meant that the number of privately owned Industrial Training Centers (ITCs) have exponentially grown to challenge the monopoly of state-owned ITIs for skill-training of workers. Both the ITCs and the ITIs are now increasingly concentrated in the southern and western parts of the country (regions with the largest share of manufacturing hubs) to attract students desperate to get a foothold in industrial jobs, even if such jobs are becoming more precarious, badly paid and temporary in nature. However, this is not to discount the role played by ITIs located in the de-industrialized parts of India, for instance in states like West Bengal, where the desperation of students to secure jobs are utilized to create a docile and heavily exploited labour force in both the industrial as well as postindustrial sectors.

As we have argued in this paper, in both the planned economic model as well as under free-market liberalization in India, ITIs have utilized skill for imparting competence as well as creating a 'committed', responsible and disciplined work-force. The pedagogic instructions and institutional forms of the ITIs have changed to reflect the different models of labour control and disciplining necessitated by the shift from planned economy to free-market neo-liberalism in India. Furthermore, while the ITIs have been partially successful in promoting social mobility of workers through enhanced and credentialed skill-training (for instance for the permanent work force in state run companies) but they have also been largely responsible for crafting a large pool of precarious, cheap and disposable workers who have found themselves essentially at the bottom rungs of the technological work-force in India.

In sum, ITI training has shifted from producing workers for the public sector to the re-production of skilled labour for private capital from at least the 1990s. Secondly and more importantly, as our interviews suggest, the labour force produced by the ITIs is essentially a precarious and vulnerable one. This is because of the limited choice of employment opportunities that most ITI graduates experience, given the lack of industrial manufacturing bases in West Bengal. Hence ITIs as institutions are failing in 
West Bengal at least to lead to a sustained social mobility for workers. But the relative precariousness of ITI trained workers in West Bengal is being utilized by other industrially advanced states/regions for ensuring a supply of a docile and cheap labour force.

\section{Bibliography}

Agrawal, Tushar, "Vocational education and training in India: Challenges, status and labour market outcomes". Journal of Vocational Education \& Training, 64 no.4(2012): 453-474.

Braverman, Harry. Labor and monopoly capital: The degradation of work in the twentieth century. New York: Monthly Review Press, 1974.

Breman, Jan. "The study of industrial labour in post-colonial India-the informal sector: A concluding review." In The Worlds of Indian Industrial labour, edited by Jonathan Parry, Jan Breman, and Karin Kapadia. New Delhi: Thousand Oaks, 1999.

Crisp, Jeff. "Productivity and protest: Scientific management in the Ghanaian gold mines, 1947-1956." In Struggle for the city: migrant labour, capital, and the state in urban Africa, edited by Frederick. Cooper, 91-131. London: Sage, 1983.

Cross, Jamie. Dream zones. Anticipating capitalism and development in India. London: Pluto, 2014.

Engels, Friedrich. The condition of the working class in England. London: Oxford University Press, 1993.

Gasskov, Vladimir., Aggarwal, Ashwani., Grover, Anil., Juneja, Q.L. \& Infocus Programme on Skills, Knowledge and Employability. "Industrial training institutes of India: the efficiency report. International Labour Organisation". Subregional Office for South Asia (ILO), 2003. Accessed June 25, 2018. http://www.voced.edu.au/content/ngv:1141

Goel, Vijay. P. “Technical and vocational education and training (TVET) system in India for sustainable development". Ministry of human resource development report, 1-2, 2011. Accessed August 5, 2018. http://adapt.it/adapt-indice-a-z/wp content/uploads/2014/09/VT Sustainable Dev.pdf 
Government of India. National Policy for Skill Development and Entrepreneurship. New Delhi: Ministry of Skill Development and Entrepreneurship, 2015.

Hobsbawm, Eric. J., Labouring men: Studies in the history of labour. London: Weidenfeld and Nicolson, 1968.

Holmström, Mark. Industry and inequality: The social anthropology of Indian labour. Cambridge: Cambridge University Press, 1984.

International Labour Organization (ILO). A Skilled Workforce for Strong, Sustainable and Balanced Growth: A G20 Training Strategy. Geneva: International Labour Organization, 2011.

International Labour Organization (ILO). World Employment Social Outlook: Trends 2018. Geneva: International Labour Organization, 2018.

Jahan, Selim. Human Development Report 2016: Human Development for Everyone. New York: United Nations Development Programme, 2016.

Jeffrey, Craig. Timepass: Youth, class and the politics of waiting in India. Stanford: Stanford University Press, 2010.

Kohli, Atul, "Politics of economic growth in India, 1980-2005: Part I: The 1980s". Economic and Political Weekly, 41 no.14(2006):1251-1259.

Kohli, Atul. Poverty amid plenty in the new India. New Delhi: Cambridge University Press, 2012.

Kumar, Kothandaraman. "ITIs / ITCs: Industrial Training Institutes / Industrial Training Centres." In India: Preparation for the World of Work, edited by Matthias. Pilz, 65-80. Wiesbaden: Springer VS, 2016.

Levien, Michael, "The land question: Special Economic Zones and the political economy of dispossession in India." The Journal of Peasant Studies, 39 no. 3-4(2012): 933-969.

Levien, Michael, "Regimes of dispossession: From steel towns to special economic zones”. Development and change, 44 no. 2(2013a):381-407.

Levien, Michael, “The politics of dispossession: Theorizing India's 'land wars'”. Politics \& Society, 41 no. 3(2013b):351-394.

Levien, Michael, "From primitive accumulation to regimes of dispossession". Economic and Political Weekly, 50 no. 22(2015): 351-394.

Maitra, Saikat, and Maitra, Srabani, “Tapping into the 'standing-reserve': A comparative analysis of workers' training programs in Kolkata and Toronto". Studies in Continuing Education, 37 no. 3(2015): 317-332.

Majumdar, Shyamal. "Forward: Reflections on Opportunities and Challenges of Skills Development in India." In India: Preparation for the World of Work. Education System and School to Work Transition edited by Matthias Pilz, 7-14. Wiesbaden : Springer VS, 2016. 
Mehrotra, Vinay Swarup, "Integrating academic and vocational education: Making the link through national vocational education qualifications framework". COMOSA Journal of Open Schooling, 3 no. 1(2012):30-48.

Mehrotra, Santosh, and Mehrotra, Vinay Swarup. "Challenges Beyond Schooling: Innovative Models for Youth Skills Development in India." In Transitions to Post-School Life. Education in the Asia-Pacific Region: Issues, Concerns and Prospects, edited by Margarita Pavlova, John Chi-Kin Lee and Rupert Maclean, 13-34, vol 41. Singapore: Springer, 2018.

Mitra, Arup, and Verick, Sher. Youth employment and unemployment: An Indian perspective. New Delhi: International Labour Organization, 2013.

Morris, Morris. David. (1965). The emergence of an industrial labor force in India: A study of the Bombay cotton mills, 1854-1947. Berkeley \& London: University of California Press.

National Skill Development Corporation (2012-2017). Executive Summary for the State of West Bengal (2012-17, 2017-22). New Delhi: NSDC.

Nayana Tara, S., and Sanath Kumar, N.S, "Skill development in India: In conversation with S. Ramadorai, Chairman, National Skill Development Agency \& National Skill Development Corporation; former CEO, MD and Vice Chairman, Tata Consultancy Services". IIMB Management Review, 28 (2016): 235-243.

Parmar, D. K., Dave, S. K., and Jain, A. K, "Empowerment of Dalits through vocational education and training". International Journal of Scientific Research, 4 no. 9 (2015): 8689.

Parry, Jonathan. P, "Lords of labour: Working and shirking in Bhilai." Contributions to Indian Sociology, 33 no. 1-2(1999): 107-140.

Parry, Jonathan. P., and Strümpell. Christian, “On the desecration of Nehru's 'temples': Bhilai and Rourkela compared". Economic and Political Weekly, 43 no. 19 (2008): 47-57.

Pilz, Matthias. India: Preparation for the World of Work. Education System and School to Work Transition. Wiesbaden : Springer VS, 2016.

Planning Commission. "Coordinated action on skill development. New Delhi:

Government of India”, 2008. Accessed July 27, 2018.

http://planningcommission.gov.in/reports/genrep/skilldev/rep_skilldev1.pdf

Roy, Srirupa. Beyond belief: India and the politics of postcolonial nationalism. Durham: Duke University Press, 2007.

Sanchez, Andrew, "Questioning success: Dispossession and the criminal entrepreneur in urban India". Critique of Anthropology, 32 no. 4(2012): 435-457.

Sanchez, Andrew. Criminal Capital: Violence, Corruption and Class in Industrial India. New York: Routledge, 2016. 
Sen, Biman, "Development of technical education in India and state policy-A historical perspective." Indian Journal of history of Science, 24 no. 2(1989): 224-248.

Subramanian, Ajantha, "Making merit: The Indian Institutes of Technology and the social life of caste". Comparative Studies in Society and History, 57 no. 02(2015): 291322.

Standing, Guy. The precariat: The new dangerous class. London: Bloomsbury Revelations, 2014.

West Bengal, (2017). Skill Development Ecosystem. West Bengal: Paschim Banga Society for Skill Development.

\footnotetext{
' https://www.oecd.org/cfe/leed/Skills\%20Development\%20Pathways\%20in\%20Asia FINAL\%20VERSION.pdf

i" https://www.oecd.org/cfe/leed/Skills\%20Development\%20Pathways\%20in\%20Asia FINAL\%20VERSION.pdf

iii http://www.ibef.org/blogs/skill-india-kaushal-bharat-kushal-bharat

iv http://pib.nic.in/newsite/PrintRelease.aspx?relid=123296

${ }^{v}$ http://dget.nic.in/content/institute/key-statistics.php

vi http://dget.nic.in/content/institute/key-statistics.php
} 